DOI https://doi.org/10.30525/978-9934-26-173-2-31

\title{
СУЧАСНІ ПЕДАГОГІЧНІ ТЕХНОЛОГІЇ В ПОЧАТКОВІЙ ШКОЛІ
}

\author{
Марчук Л. М. \\ кандидат психологічних наук, дочент, \\ доцент кафедри загальної педагогіки та педагогіки вищої школи \\ Ужггородський національни університет \\ Павлюк Ю. А. \\ студентка 4 курсу \\ факультету суспільних наук \\ Ужсгородський начіональни університет \\ Рущак Е. В. \\ студентка 4 курсу \\ факультету суспільних наук \\ Ужггородський начіональни університет \\ м. Ужгород, Украӥна
}

Сучасне суспільство та нові стандарти іншого покоління висувають принципово нові вимоги до системи освіти. Метою освіти стає загальнокультурний, особистісний та пізнавальний розвиток учнів, що забезпечує таку ключову компетенцію освіти як «навчити вчитися». На відміну від попередніх традиційних вимог освіти - це, по-перше, не просто закласти в голови учнів заданий обсяг знань, а й подбати про те, щоб це були знання актуальні, по-друге, зробити все необхідне, щоб учень зміг усвідомлено та ефективно застосовувати отримані знання у своєму житті. Найважливішим завданням сучасної системи освіти $\epsilon$ формування універсальних навчальних дій, які забезпечують школярам вміння вчитися, здатність до саморозвитку та самовдосконалення. Це вимагає змін у підходах і методах навчання. У зв'язку з цим, актуальним стає впровадження у процес навчання, починаючи з початкової освіти, нововведень, які полягають у паралельному використанні традиційних методів та організаційних форм навчання і нових освітніх, педагогічних та інформаційних (комп’ютерних) технологій.

Термін «освітні технології» - більш ємний, ніж «технології навчання», бо він передбачає ще й виховний аспект, пов'язаний із формуванням і розвитком особистісних якостей учнів початкової школи. Педагогічні технології - це складна система засобів і методик, об'єднаних пріоритетними загальноосвітніми цілями, концептуально 
взаємопов'язаними між собою завданнями і змістом, формами й методами організації навчально-виховного процесу, де кожна позиція накладає відбиток на всі інші, що і створює в результаті певну сукупність умов для розвитку учнів [1].

До сучасних освітніх технологій можна віднести: технологію дистанційного навчання, технологію продуктивного навчання, здоров'язберігаючі технології, інформаційно-комунікаційні технології, навчання у співпраці (командна, групова робота); технологію використання в навчанні ігрових методів, розвиваюче навчання, проблемне навчання, колективну систему навчання, технологію розвитку критичного мислення та інші. Сучасні педагогічні технології пропонують інноваційні моделі побудови такого навчального процесу, де на перший план висувається взаємопов'язана діяльність вчителя й учня, націлена на вирішення як навчальних, так і практично значущих завдань.

Здоров'язбережуючі технології: найдорожчий дар, який людина отримує від природи - здоров'я. Перед вчителями початкових класів поставлено завдання у збереженні, зміцненні фізичного та психічного здоров'я дітей, що вступають до школи. Основна мета цих технологій скерована на збереження, зміцнення, відтворення та передачу здоров'я майбутнім поколінням. Діти відчувають величезну потребу в русі, що $\epsilon$ для них засобом пристосування до життя, пізнання навколишнього світу. Комплексне використання здоров'язберігаючих технологій у навчальному та виховному процесі дозволяє знизити стомлюваність, покращує емоційний настрій і підвищує працездатність молодших школярів, а це, зі свого боку, сприяє збереженню та зміцненню їхнього здоров'я.

Навчання в співпраці (групова робота). В основі стратегії співробітництва лежить ідея стимулювання і спрямування педагогом пізнавальних інтересів учнів. Динаміка становлення спільної діяльності вчителя й учнів. Перша фаза - залучення до діяльності - включає такі форми: розподіл між учителем і учнями дій; імітація дій учнями; наслідування дій учнями. Друга фаза - узгодження діяльності учнів 3 учителем - включає: саморегулюючі дії учнів; самоорганізовані дії учнів; самоспонукальні дії учнів. Третя фаза - партнерство, що передбачає суб'єкт-суб'єктну взаємодію в удосконаленні освоєння діяльності. Результатом цього процесу є формування в учнів здатності організовувати групову роботу (планування дій, розподіл ролей, дотримування норм співпраці тощо), а також самостійно ініціювати спільну діяльність. Необхідність об'єднання дітей у групи для виконання завдання виникає в таких випадках: завдання не може бути виконано індивідуально; спільне обговорення значно пришвидшує процес пошуку 
вирішення; завдання потребує розподілу етапів (операцій) виконання між членами групи [3].

Ігрові технології дозволяють здійснювати диференційований підхід до учнів, залучати кожного учня в роботу, з огляду на його інтерес, схильність, рівень підготовки $з$ предмета. Вправи ігрового характеру збагачують учнів новими враженнями, виконують розвиваючу функцію, знімають стомлюваність. Вони можуть бути різноманітними за своїм призначенням, змістом, засобами організації і проведення. 3 їхньою допомогою можна розв'язувати яке-небудь одне завдання (удосконалювати обчислювальні, граматичні навички тощо) або ж цілий комплекс завдань: формувати мовленнєві вміння, розвивати спостережливість, увагу, творчі здібності та ін. Феномен її в тому й полягає, що, являючись розвагою, відпочинком, вона здатна перерости в навчання, у творчість.

Інформаційно-комунікативні технології - це сукупність методів i технічних засобів реалізації інформаційних технологій на основі комп'ютерних мереж і засобів забезпечення ефективного процесу навчання. Змінюється роль вчителя в інформаційній культурі - він має стати координатором інформаційного потоку, а отже активно застосовувати під час навчання дітей інформаційно-комунікативні технології. Уроки з використанням комп'ютерних технологій дозволяють зробити їх більш цікавими, продуманими, мобільними, особливо в початковій школі. Учні 1-4 класів мають наочно-образне мислення, тому дуже важливо будувати їхнє навчання, застосовуючи якнайбільше якісного ілюстративного матеріалу, залучаючи у процес сприйняття зір, слух, емоції, уяву. Мультимедійний супровід на різних уроках у початковій школі дозволяє перейти від пояснювально-ілюстрованого способу навчання до діяльнісного, у якому дитина стає активним суб'єктом навчальної діяльності.

Технологія проблемного навчання - форма організації навчальновиховного процесу 3 допомогою проблемних завдань i проблемних ситуацій, які надають навчанню пошуковий, дослідницький та інтерактивний характер. Актуальність даної технології визначається розвитком високого рівня мотивації до навчальної діяльності, активізації пізнавальних інтересів учнів, що стає можливим за умови вирішення виникаючих протиріч, створення проблемних ситуацій на уроці. У подолання посильних труднощів в учнів виникає постійна потреба в оволодінні новими знаннями, новими способами дій, вміннями й навичками.

Технології формування творчої особистості, основне завдання якої створити максимально сприятливі умови для творчого розвитку дітей молодшого шкільного віку. Технологія формування творчого учня 
орієнтована на особистість. Це означає максимальну індивідуалізацію й диференціацію навчального процесу. Вчитель, який формує творчу особистість, повинен бути новатором за суттю своєю: впроваджувати нові ідеї та різноманітні інновації в навчально-виховний процес. I тільки тоді буде перебудовано всю систему виховання й навчання в бік підвищення ії ефективності [2].

Також новими технологіями у початковій школі виступають: «фішбоун» - графічна техніка представлення інформації дозволяє образно продемонструвати хід аналізу будь-якого явища через виділення проблеми, з'ясування ii причин та підтверджуючих фактів i формулювання висновку з питання; кейс-метод - це засіб активного проблемно-ситуаційного аналізу, що грунтується на навчанні шляхом розв'язування задач-ситуацій (кейсів). Головне його призначення не надання готових знань, а розвиток в учнів здатності розв'язувати проблеми і знаходити їх рішення самостійно; QR-код - це графічне зображення, в якому зашифрована певна інформація, посилання на сайт чи окрему його сторінку. Зчитування QR-коду відбувається за допомогою звичайної камери типового смартфона. Для цього на ньому має бути попередньо встановлена відповідна програма-сканер; мобільне навчання, яке тісно пов'язане 3 електронним та дистанційним навчанням, відмінністю $є$ використання мобільних пристроїв. Використання у освітній діяльності сучасних педагогічних технологій дозволяє урізноманітнити навчальний процес, але при цьому варто пам'ятати, що використання усіх технологій може спровокувати перевтому учнів, тому варто застосовувати їх на різних предметних уроках або ж тільки елементи.

Таким чином, на основі застосування сучасних педагогічних технологій на уроках у початковій школі забезпечується нова якість освіти. Комбінування прийомів допомагає навчити дітей застосовувати ці технології самостійно, щоб вони могли стати незалежними та грамотними мислителями та із задоволенням навчалися протягом усього життя.

\section{Література:}

1. Ворожейкіна О. М. 100 цікавих ідей для проведення уроку. Х.: Вид. група «Основа», 2011. - 287 с.

2. Дичківська І.М. Інноваційні педагогічні технології: підручник / I.М. Дичківська. - 2-ге вид. - Київ: Академвидав, 2012. - 352 с.

3. Підготовка майбутнього вчителя до впровадження педагогічних технологій / за ред. І. Зязюна, О. Пехоти. - Київ: Вид-во А.С.К., 2003. $-240 \mathrm{c}$. 